\title{
Postępy w leczeniu chorych na chłoniaka Hodgkina
}

\author{
Advances in the treatment of patients with Hodgkin lymphoma
}

\author{
Tomasz Wróbel \\ Klinika Hematologii, Nowotworów Krwi i Transplantacji Szpiku, Uniwersytet Medyczny, Wrocław
}

\begin{abstract}
Streszczenie
Chtoniak Hodgkina (HL) należy do nowotworów uktadu chtonnego o dobrym rokowaniu. W niniejszym artykule podsumowano osiagniecia $w$ diagnostyce i leczeniu chorych na HL w ostatnim 5-leciu. Najwazniejsze z tych osiagnięć to wykorzystanie badania za pomoca pozytonowej tomografi emisyjnej we wczesnej ocenie skuteczności leczenia oraz wprowadzenie przeciwciat monoklonalnych $w$ strategiach terapeutycznych nawrotowych postaci $H L$.
\end{abstract}

Słowa kluczowe: chłoniaka Hodgkina. pozytonowa tomografia emisyjna, brentuksymab vedotin

Hematologia 2015; 6, 1: 44-51

\begin{abstract}
Hodgkin lymphoma (HL) is lymphoid neoplasm showing a favourable patient prognosis. This article summarizes advances made within the last 5 years in the treatment of patients with HL; the most important being positron emission tomography used for assessing early on how effective treatments are and for cases where monoclonal antibodies in relapse settings are introduced.
\end{abstract}

Key words: Hodgkin lymphoma, positron emission tomography, brentuximab vedotin

Hematologia 2015; 6, 1: 44-51

\section{Wprowadzenie}

Chłoniak Hodgkina (HL, Hodgkin lymphoma) należy do nowotworów o bardzo dobrym rokowaniu, jednak nadal u około $10 \%$ chorych na HL we wczesnych stadiach i u około $30 \%$ pacjentów $z$ HL w stadiach zaawansowanych dochodzi do nawrotu lub/i oporności. Nadal wiele aspektów postępowania terapeutycznego w tej chorobie wymaga poprawy. Do najważniejszych wyzwań w opiece nad chorymi z HL należą: 1) optymalizacja chemio- i radioterapii pozwalająca na osiągnięcie jak najlepszych wyników przy ograniczeniu toksyczności wczesnej i późnej; 2) znalezienie właściwej roli wczesnej oceny za pomocą pozytonowej tomografii emisyjnej (PET, positron emission tomography)/tomografii komputerowej (CT, computed tomography) w modyfikacji leczenia; 3) ustalenie skutecznej terapii postaci nawrotowych, a szczególnie nawrotów wysokiego ryzyka i postaci opornych; 4) poprawa efektów leczenia starszych pacjentów. Spośród wyników wielu badań, które przyczynily się do poprawy diagnostyki i leczenia chorych na HL w ostatnich latach, wybrano te, które, zdaniem autora, przynoszą odpowiedzi na powyższe wyzwania, a w niektórych przypadkach zmieniły praktykę kliniczną.

Omawiając współczesne zasady postępowania $z$ chorymi na HL, należy się odnieść do opublikowanej w 2014 roku zmodyfikowanej w Lugano klasyfikacji Ann Arbor [1]. Spośród nich na podkreślenie zasługują następujące zalecenia:

- badanie PET/CT jest preferowane w określeniu stopnia zaawansowania chłoniaków

Adres do korespondencji: Tomasz Wróbel, Klinika Hematologii, Nowotworów Krwi i Transplantacji Szpiku, Uniwersytet Medyczny, ul. Pasteura 4, 50-367 Wrocław, tel. 7178425 76, mail: tomasz_wrobel@wp.pl 
FDG-awidnych, a do takich jest zaliczany HL. U chorych na HL $z$ wykonanym wyjściowym badaniem PET/CT nie jest wymagana rutynowa biopsja szpiku kostnego w określeniu stadium zaawansowania choroby;

- monitorowanie po uzyskaniu remisji powinno się opierać na wnikliwej ocenie klinicznej, dokładnym wywiadzie i badaniu przedmiotowym. Nie zaleca się rutynowego wykonywania badań obrazowych. Fałszywie dodatni wynik PET sięga nawet $20 \%$ przypadków, prowadząc do wykonywania niepotrzebnych badań, dalszej ekspozycji chorych na promieniowanie, biopsje, zwiększenie kosztów i niepokoju chorego.

\section{Biologiczne i kliniczne czynniki prognostyczne}

Określenie czynników prognostycznych jest nieodzownym składnikiem racjonalnego postępowania przeciwnowotworowego. W rutynowej praktyce planowanie terapii ocenia się na podstawie klinicznych czynników prognostycznych, z których najważniejsze to stadium zaawansowania choroby według zmodyfikowanej w Lugano klasyfikacji z Ann Arbor [1]. W ostatnich latach coraz większe znaczenie zyskuje wczesna ocena PET/CT oraz nowe wskaźniki biologiczne związane $z$ mikrośrodowiskiem zajętych chorobowo węzłów chłonnych.

Steidl i wsp. [2] wykazali rokownicze znaczenie makrofagów CD68 + u chorych na HL. Autorzy ci udowodnili wyraźną korelację między odsetkiem komórek CD68+ w materiale biopsyjnym a czasem do progresji choroby (PFS, progression-free survival) i czasem przeżycia całkowitego (OS, overall survival). Mediana PFS była istotnie krótsza u chorych $z$ większym odsetkiem makrofagów niż pacjentów z mniejszym odsetkiem tych komórek w nacieku. Obserwacje te dotyczyły zarówno chorych na HL w stadiach wczesnych, jak i zaawansowanych. Natomiast Deau i wsp. [3], badając wpływ mikrośrodowiska na przebieg kliniczny choroby, dokonali retrospektywnej analizy, w której udowodnili, że oporny HL jest związany ze zwiększonym odsetkiem mastocytów w mikrośrodowisku. Mastocyty i makrofagi mogą zwiększać oporność komórek Reed-Sternberga (R-S) na chemioterapię, zaś mikrośrodowisko stanowi potencjalny cel terapii HL $[2,3]$.

Connors i wsp. [4] zakwestionowali zasadność stosowania europejskich klasyfikacji - GHSG (German Hodgkin Sudy Group) EORTC (European Organisation for the Research and Treatment of Cancer) - wczesnych stadiów choroby na niskie i pośrednie/wysokie ryzyko. W retrospektywnej analizie pacjenci w stadium IIA $z$ bulky i IIB byli leczeni podobnie jak chorzy w stadiach zaawansowanych czyli 6-8 cyklami ABVD (adriamycyna, bleomycyna, winblastyna, dakarbazyna). Odsetek nawrotów w tej grupie chorych był taki sam jak w stadiach zaawansowanych i wynosił około $20 \% \mathrm{w}$ przeciwieństwie do pacjentów w stadiach IA i IIA, u których odsetek nawrotów wynosi około 5\%. Przebieg kliniczny choroby zaliczanej do stadiów wczesnych $z$ obecnością niekorzystnych czynników ryzyka nie odbiega zatem od stadiów zaawansowanych. Badanie to wskazuje na niekorzystne znaczenie obecności dużej masy węzłowej (bulky disease) niezależnie od stadium klinicznego choroby [4].

Międzynarodowy Wskaźnik Prognostyczny (IPS, International Prognostic Score) zaproponowany w 1998 roku, na który składają się: wiek powyżej 45 lat, płeć męska, IV stadium zaawansowania klinicznego choroby według klasyfikacji z Ann Arbor, niedokrwistość (hemoglobina $<10,5 \mathrm{~g} / \mathrm{dl}$ ), stężenie albumin poniżej $4 \mathrm{~g} / \mathrm{dl}$, leukocytoza poniżej $15 \mathrm{G} / \mathrm{l}$, limfopenia poniżej $0,6 \mathrm{G} / 1$ lub poniżej $8 \% \mathrm{w}$ rozmazie krwi obwodowej, był ważnym narzędziem do stratyfikacji chorych na HL w zaawansowanej postaci. Poprawa wyników leczenia sprawiła jednak, że w ostatnich latach kwestionuje się predykcyjne znaczenie IPS. Badacze amerykańscy zaprezentowali nowy, uproszczony 3-czynnikowy wskaźnik prognostyczny (PS-3, 3-factor prognostic score). Na podstawie prospektywnej analizy 854 chorych ustalono, że jedynie 3 czynniki ryzyka $z$ oryginalnego IPS wpływają na PFS i OS, w tym wiek powyżej 45. roku życia, stężenie hemoglobiny poniżej $10,5 \mathrm{~g} / \mathrm{dL}$ oraz IV stadium klinicznego zaawansowania choroby. W zależności od liczby tych czynników określono cztery grupy ryzyka: brak czynników ryzyka, 1, 2 lub obecność 3 czynników ryzyka; 5-letni PFS wynosił odpowiednio 83\%, $74 \%, 68 \%$ i $63 \%$, a OS - 95\%, 85\%, $75 \%$ i $52 \%$ [5].

\section{Optymalizacja leczenia pierwszej linii}

Rozwój badań obrazowych PET/CT sprawił, że podejmowane są próby modyfikacji leczenia zależnie od wczesnego wyniku PET (zwykle po 2. cyklu chemioterapii). Ponadto kontrowersyjna pozostaje rola radioterapii, szczególnie we wczesnych stadiach choroby. Mimo postępu, jaki się dokonał w zakresie technik napromieniania, ograniczających ekspozycję zdrowych tkanek i zmniejszających dawkę promieniowania, ciągle istnieją obawy dotyczące toksyczności związanej $z$ radioterapią. 


\section{Wczesne stadia HL}

Porównanie chemioterapii z leczeniem skojarzonym (chemio- i radioterapia) w leczeniu chorych na HL we wczesnych stadiach była przedmiotem badania amerykańsko-kanadyjskiego NCIC CTG/ECOG. Wyniki tego badania przedstawione na konferencji ASH (American Society of Hemato$\operatorname{logy}$ ) w $2011 \mathrm{roku}$, a następnie dane opublikowane w „New England Journal of Medicine” stanowity aktualizację po 12 latach obserwacji badania, którego rezultaty pierwotnie opublikowano w 2005 roku. Pacjenci $z$ HL w stadium I-IIA według klasyfikacji z Ann Arbor byli poddani randomizowani do grupy otrzymującej wyłącznie chemioterapię lub do grupy leczenia skojarzonego. Przed randomizacją chorzy byli stratyfikowani do grup niskiego i wysokiego ryzyka według czynników ryzyka, takich jak: typ histologiczny LP (lymphocyte predominance) lub NS (nodular sclerosis), wiek poniżej 40 lat, odczyn Biernackiego (OB) poniżej 50 i zajęcie nie więcej niż trzech grup węzłów chłonnych. W grupie $z$ zastosowaniem uzupełniającej radioterapii chorzy cechujący się niskim ryzykiem byli poddawani jedynie subtotalnemu napromienianiu węzłów chłonnych (STNI, subtotal nodal irradiation), a chorzy obarczeni wysokim ryzykiem byli leczeni za pomocą 2 cykli ABVD (adriamycyna, bleomycyna, winblastyna, dakarbazyna) + STNI. W grupie bez radioterapii wszyscy chorzy zależnie od odpowiedzi otrzymywali 4-6 cykli ABVD. Odległe wyniki były odmienne od pierwotnie opublikowanych, gdyż OS w obserwacji 12-letniej było najwyższe w grupie leczonej jedynie ABVD i wynosiło $94 \%$ w porównaniu z 87\% w grupie osób poddanych leczeniu skojarzonemu. Przewaga ta wynikała głównie $z$ mniejszej liczby późnych następstw leczenia, takich jak wtórne nowotwory i powikłania sercowo-naczyniowe [6]. Wyniki tego badania wskazują na późną toksyczność radioterapii i stanowią wskazówkę, że w chorobach o dużym odsetku wyleczeń bardzo ważna jest długoletnia obserwacja chorych. Korzyść ze stosowania radioterapii polega głównie na uzyskaniu lepszej kontroli choroby wyrażającej się poprawą PFS; ten korzystny efekt jest jednak niwelowany późną toksycznością związaną z uzupełniającym napromienianiem. Trzeba podkreślić, że współcześnie w leczeniu chorych na HL we wczesnych stadiach stosuje się znacznie mniej radykalne techniki radioterapii, takie jak radioterapia na zajęte pola (IF-RT, involved field radiotherapy) czy radioterapia na zajęte węzły chłonne (involved nodal irradiation), co — być może — się przyczyni do ograniczenia późnych następstw leczenia skojarzonego.
Próby ograniczenia radioterapii we wczesnych stadiach HL przedstawiono w dwóch badaniach z wykorzystaniem wczesnej oceny PET/CT. Podstawą koncepcji terapii zależnej od wczesnej odpowiedzi klinicznej są dane, $z$ których wynika, ze chorzy $z$ ujemnym wynikiem badania PET - PET $(-)$ - po drugim cyklu chemioterapii należą do grupy korzystnego ryzyka. W brytyjskim badaniu RAPID u chorych w stadium I lub IIA bez bulky w śródpiersiu po 3 cyklach ABVD wykonywano badanie PET. Pacjenci PET(+) otrzymywali czwarty cykl ABVD oraz IF-RT, natomiast pacjentów PET(-) poddawano randomizacji do dwóch grup, z których jedna otrzymywała IF-RT (30 Gy), a w drugiej nie prowadzono dalszego leczenia poza wyjściowymi 3 cyklami ABVD. Ocena wyników leczenia zgodnie $z$ planowaną alokacją pacjentów wykazała, że 3-letni PFS był nieco wyższy u chorych PET(-) poddanych radioterapii $93,8 \%$ w porównaniu $z$ 90,7\% w grupie bez dalszego leczenia. Jednak, analizując PFS w zależności od rzeczywiście zastosowanego leczenia (28 chorych nie otrzymało zaplanowanej radioterapii), stwierdzono, że różnice te były większe i wynosiły odpowiednio $97 \%$ w porównaniu z $90,7 \%$. Mieściły się one w wyjściowym statystycznym założeniu 7-procentowego marginesu między badanymi grupami. Jednocześnie chorzy PET(-) nieleczeni, u których doszło do wznowy, byli skutecznie leczeni radio- lub chemioradioterapią; jedynie 4 spośród 20 pacjentów w tej grupie poddano przeszczepieniu autologicznych krwiotwórczych komórek macierzystych (auto-HSCT, autologous hematopoietic stem cells transplantation). Autorzy konkludują, że w stadium IA/IIA HL radioterapia nie jest konieczna u 75\% chorych, u których uzyskano negatywizację wyniku badania PET po 3 cyklach ABVD [7]. Warto jednak podkreślić, że przedstawione dane mają wstępny charakter ze wzgledu na krótki okres obserwacji oraz relatywnie niewielką liczebność badanych grup. Ponadto kluczowe znaczenie $\mathrm{w}$ terapii zależnej od wczesnego wyniku PET ma wiarygodna ocena tego badania według skali Deauville.

Odmienne od powyższych wyniki przedstawiono natomiast we wczesnej analizie innego badania, które dotyczyło podobnej jak RAPID populacji pacjentów leczonych zależnie od wyniku badania PET pod drugim cyklu ABVD [8]. W tym badaniu wykazano, ze nawet u chorych $z$ negatywizacją badania PET po drugim cyklu chemioterapii ryzyko wczesnej wznowy u osób nienapromienianych jest znacząco wyższe niż w grupie osób poddanych leczeniu skojarzonemu. 
Dwa powyższe badania są pierwszymi randomizowanymi próbami klinicznymi $z$ wykorzystaniem wczesnej oceny PET/CT u chorych na HL do modyfikacji leczenia i, niestety, nie pozwalają na jednoznaczne wskazanie optymalnego sposobu postępowania.

Rola uzupełniającej radioterapii u chorych z zaawansowanym HL po chemioterapii pozostaje przedmiotem kontrowersji. Przykładem wykorzystania oceny PET/CT do modyfikacji postępowania terapeutycznego $\mathrm{u}$ takich chorych jest badanie HD15 GHSG (German Hodgkin Lymphoma Study Group); jednym z jego celów było ograniczenie zastosowania radioterapii u pacjentów $\mathrm{Z}$ chorobą resztkową (MRD, minimal residual disease) po zakończonej chemioterapii. Wśród 2137 chorych uczestniczących w tym badaniu wyodrębniono 728 pacjentów $z$ MRD utrzymującą się po chemioterapii według programu BEACOPP (bleomycyna, etopozyd, doksorubicyna, cyklofosfamid, winkrystyna, prokarbazyna, prednizon), określoną jako guz ponad $2,5 \mathrm{~cm}$. W tej grupie chorych było $74,2 \%$ osób PET(-) i $25,8 \%$ PET(+). W grupie PET(-) u 28 chorych wystąpił nawrót lub zastosowano radioterapię mimo negatywnego badania PET $(n=8)$, co pozwoliło określić negatywną wartość prognostyczną (NPV, negative prognostic value) tego badania na $94,6 \%$; 3-letni PFS od wykonania badania PET wynosił $92,1 \%$ w grupie PET(-) i 86,1\% w grupie PET(+). Tylko $11 \%$ chorych poddano dodatkowej radioterapii w porównaniu $z 71 \%$ po BEACOPP $\mathrm{w}$ dawkach eskalowanych (BEACOPPesc, BEACOPP escalated) w poprzednim badaniu HD9. Nie stwierdzono natomiast różnic w PFS i OS w porównaniu $\mathrm{z}$ poprzednimi badaniami w zaawansowanych postaciach HL; NPV badania PET wynosząca 0,95 wskazuje, że w przypadku obecności MRD tylko chorzy PET(+) wymagają dodatkowej radioterapii. Chorzy PET(-) po BEACOPP nie wymagają uzupełniającej radioterapii. Wyniki tego badania wskazują, że - planując terapię według wyników badania PET/CT — można ograniczyć toksyczność bez zmniejszenia skuteczności leczenia [9].

Wśród klinicystów zajmujących się leczeniem HL od wielu lat toczy się dyskusja, który ze schematów chemioterapii - ABVD czy też może bardziej intensywne (BEACOPP, BEACOPPesc) - są najlepsze w leczeniu chorych na HL w zaawansowanych stadiach. W poszukiwaniu odpowiedzi na to pytanie Skoetz i wsp. [10] dokonali metaanalizy obejmującej ponad 10 tys. chorych z 14 badań klinicznych z zastosowaniem różnych cykli chemioterapii, wykazując, że zastosowanie 6 cykli BEACOPPesc lub 8 cykli BEACOPP poda- wanych co $14 \mathrm{dni}$ (BEACOPP-14) istotnie obniza ryzyko zgonu w porównaniu z ABVD; przewaga 8 cykli BEACOPPesc nad ABVD - jakkolwiek mniejsza - była również znacząca statystycznie. Mimo ograniczeń związanych $z$ faktem, że niektóre protokoły oceniano $\mathrm{w}$ pojedynczych badaniach, autorzy wnioskują, że w leczeniu I linii u chorych na zaawansowane postaci HL zarówno 6 cykli BEACOPPesc, jak i 8 cykli BEACOPP-14 wykazuje przewage nad ABVD w odniesieniu do OS [10]. Jednocześnie w 10-letniej obserwacji włoskiego badania H2000, w którym ABVD porównywano $\mathrm{z}$ bardziej intensywną chemioterapią (m.in. BEACOPP), udowodniono, że początkowe korzyści z intensywnego leczenia są niwelowane większym odsetkiem wtórnych nowotworów [11]. W podsumowaniu należy stwierdzić, że protokół BEACOPP pozwala na uzyskanie większego odsetka całkowitych remisji (CR) w porównaniu $z$ ABVD, ale jednocześnie jest on bardziej toksyczny zarówno w odniesieniu do powikłań wczesnych (gorączka neutropeniczna), jak i późnych (wtórne nowotwory, w tym ostre białaczki i zespoły mielodysplastyczne).

Niewykluczone jednak, że w najbliższej przyszłości leczenie zaawansowanych postaci HL będzie oparte na chemioimmunoterapii. W badaniu 1. fazy przeciwciało anty-CD30 skoniugowane $z$ auristatyną (BV, brentuksymab vedotin) podano w skojarzeniu z ABVD lub AVD (adriamycyna, bleomycyna, dakarbazyna) w leczeniu I linii u chorych na zaawansowaną postać HL. Skojarzenie BV z ABVD okazało się zbyt toksyczne, głównie $z$ powodu powikłań płucnych (44\%, w tym 2 zgony), co sugeruje kumulację toksyczności BV i bleomycyny. Było ono natomiast dobrze tolerowane w skojarzeniu z AVD. Częstość powikłań neurologicznych o niewielkim nasileniu była podobna w obu grupach i przekraczała $70 \%$. W grupie leczonej AVD z BV odsetek CR wynosił 96\%. Planowane jest badanie 3 . fazy służące porównaniu ABVD z AVD w skojarzeniu z BV [12].

\section{Leczenie chorych na HL w podeszłym wieku}

Pacjenci powyżej 60. roku życia stanowią nawet do $30 \%$ wszystkich chorujących na HL. Standardem leczenia w tej populacji pozostaje ABVD, choć terapia ta jest obarczona dużą toksycznością, między innymi włóknieniem płuc w następstwie stosowania bleomycyny. Odrębności przebiegu klinicznego HL u osób w podeszłym wieku były przedmiotem analizy na podstawie amerykańskiej bazy SEER (Surveillance, Epidemiology, and End Results). W bazie tej oceniono dane 2884 chorych w wieku co najmniej 65 lat. 
U pacjentów tych częściej niż u osób młodszych choroba występuje w stadiach zaawansowanych, w lokalizacjach pozawęzłowych, a wśród podtypów histologicznych dominują LD (lymphocytes depleted) oraz MC (mixed cellularity). Co najważniejsze, roczne przeżycie starszych pacjentów było zdecydowanie gorsze - wynosiło $64 \%$ w porównaniu z $95,7 \%$ chorych młodszych. Przeżycie to pogarszało się wraz $\mathrm{z}$ zaawansowanym wiekiem i wynosiło $73,9 \% \mathrm{w}$ grupie wiekowej 65-74 lata, 56,3\% w grupie wiekowej 75-84 lata oraz $43,3 \%$ u chorych powyżej 85 . roku życia. Dane te wskazują na wysoką toksyczność oraz, wynikającą między innymi z mniejszej intensywności chemioterapii, obniżoną skuteczność leczenia przeciwnowotworowego i wskazują na konieczność ustalenia nowych metod terapeutycznych $\mathrm{w}$ tej populacji chorych [13].

Wyniki leczenia populacji starszych pacjentów w dwóch badaniach klinicznych u 117 chorych na HL we wczesnych stadiach o korzystnym i niekorzystnym ryzyku wykazały, że $-z$ powodu opóźnienia cykli i redukcji dawki - względna intensywność dawki była mniejsza niż u młodszych chorych, z powodu opóźnienia cykli i redukcji dawki. Obserwowano wysoki odsetek toksyczności (w stopniu III/IV wg Światowej Organizacji Zdrowia [WHO, World Health Organization] po 4 cyklach ABVD). Głównymi powodami zgonu były: przyczyny sercowo-naczyniowe (7\%), wtórne nowotwory (5\%), progresja/wznowa HL (5\%), toksyczność zależna od leczenia (5\%). Pięcioletni PFS wynosił 79\% w grupie HD10 i 69\% w grupie HD11 w porównaniu z 96\% (HD10) i 86\% (HD11) u młodszych chorych [14].

Badanie, którego wyniki stwarzają alternatywę dla ABVD w leczeniu chorych w starszym wieku, przeprowadzono u 59 osób z medianą wieku 68 lat (60-75 lat), głównie chorych na HL w zaawansowanych stadiach. Leczenie polegało na podaniu 6 cykli PVAG (prednizon, winblastyna, doksorubicyna, gemcytabina), jeżeli uzyskano CR po 4 cyklach lub po 8 cyklach PVA, jeśli po 4 cyklach uzyskano jedynie remisję częściową (PR, partial remission). Brak CR po zakończeniu chemioterapii był wskazaniem do uzupełniającej radioterapii. Toksyczność WHO w stopniu III/IV wystąpiła u 43 chorych (75\%), jednak tylko u 3 przerwano chemioterapię z powodu toksyczności; 10 chorych (17\%) poddano radioterapii, CR uzyskano u 46 chorych (78\%), PR zaś - u 2 (3\%). W obserwacji 37-miesięcznej u 6 chorych (10\%) wystąpiła progresja choroby, a u 9 (15\%) - wznowa, natomiast 10 chorych zmarło $z$ powodu nawrotu/progresji HL ( $2 \mathrm{w}$ przebiegu wtórnego nowotworu i $5 \mathrm{z}$ innych przyczyn) [15].
Jednym ze sposobów ograniczenia toksyczności chemioterapii w grupie starszych chorych jest zastosowanie BV w monoterapii w leczeniu I linii. Przedstawiono wyniki badania 2. fazy, w którym jest planowane włączenie 30 chorych. Dotychczas BV podano $\mathrm{w}$ standardowej dawce 13 pacjentom z medianą wieku 75 lat. Uzyskano całkowity odsetek odpowiedzi (ORR, overall response rate) na poziomie $82 \%(\mathrm{n}=9)$, w tym CR $64 \%(\mathrm{n}=7)$. Autorzy zwracają uwagę na dobrą tolerancję leczenia. Działania niepożądane w 1. i 2. stopniu to głównie neutropenia, polineuropatia oraz świąd skóry [16].

\section{Leczenie chorych $\mathrm{z}$ nawrotem $\mathrm{HL}$}

Spośród leków cytostatycznych badanych w terapii nawrotowych/opornych postaci HL warto zwrócić uwagę na bendamustynę (BEN), którą stosowano u 69 chorych we wznowie/oporności po auto-HSCT lub przeszczepieniu allogenicznych krwiotwórczych komórek macierzystych (allo-HSCT, allogeneic hemopoietic stem cells transplantation), uzyskując 25\% CR i 33\% PR i medianą czasu odpowiedzi wynoszącą około 5 miesięcy. Ciężką toksyczność hematologiczną po BEN obserwowano u $29 \%$ leczonych chorych. Na podstawie wyników uzyskanych $\mathrm{w}$ tej tak niekorzystnej rokowniczo grupie osób lek ten wydaje się wykazywać znaczącą aktywność i, być może, warto byłoby zastosować go we wcześniejszych liniach leczenia lub w kondycjonowaniu przed przeszczepieniem [17].

Wysokodawkowana chemioterapia wspomagana auto-HSCT jest standardem w terapii nawrotowego HL. Jednak w przypadkach chemioopornych lub w nawrotach wysokiego ryzyka (wznowa $<12$ miesięcy) ta forma leczenia pozwala na uzyskanie długoletnich przeżyć jedynie u około 40\% chorych. Skuteczną formę kondycjonowania przed auto-HSCT u chorych $z$ grupy wysokiego ryzyka zaproponowali Genzler i wsp. [18]. Pacjenci przed przeszczepieniem byli poddawani STNI przez $10 \mathrm{dni}$, 2 razy dziennie, dawką 150 cGy (rano na pole płaszczowe, odwrócone Y i śledzionę, a po południu na miejsca pierwotnie zajęte). Łącznie dawna wynosiła od 3000 do 3400 cGy. Następnie stosowano wysokodawkowaną chemioterapię cisplatyną, cyklofosfamidem, etopozydem; 10-letnie PFS wynosił 57\%. Wyniki były podobne $\mathrm{u}$ chorych $\mathrm{w}$ nawrocie oraz pierwotnie opornych [18].

Dla chorych na nawrotowa/oporną postać HL, szczególnie w przypadkach nawrotu po wysokodawkowanej chemioterapii wspomaganej auto-HSCT, ważną opcją leczniczą pozostaje allo-HSCT. Sureda i wsp. [19] przedstawili wyniki pro- 
spektywnego wieloośrodkowego badania służącego ocenie zastosowania allo-HSCT ze zredukowanym kondycjonowaniem (RIC, reduced intensity conditioning) - fludarabina w dawce $150 \mathrm{mg} / \mathrm{m}^{2}$ i melfalan w dawce $140 \mathrm{mg} / \mathrm{m}^{2}$. Do badania włączono 88 chorych, przy czym allo-HSCT przeprowadzono u 78 osób, w tym $70 \%$ od dawcy rodzinnego; 4-letni OS wynosił $41 \%$ i był lepszy u osób $z$ chorobą chemiowrażliwą. Typ dawcy nie miał znaczenia dla PFS. Wznowa choroby była główną przyczyną niepowodzeń i występowała częściej u chorych bez objawów przewlekłej choroby przeszczep przeciwko gospodarzowi [19].

\section{Nowe leki}

Mediana przeżycia chorych $\mathrm{w}$ nawrocie po auto-HSCT wynosi około 2,4 roku, ze szczególnie złym rokowaniem $\mathrm{u}$ chorych $\mathrm{z}$ nawrotem choroby w pierwszym roku po przeszczepieniu. Younes i wsp. [20] w badaniu 2. fazy u 102 chorych w nawrocie po auto-HSCT zastosowali średnio 9 cykli BV, uzyskując ORR na poziomie $75 \%$, w tym 33\% CR; 24-miesięczny wskaźnik OS wynosił $65 \%$. Przeprowadzono także analizę mediany przeżycia $\mathrm{w}$ zależności od odpowiedzi na leczenie - nie osiągnięto mediany u chorych w CR, u pacjentów w PR wynosiła ona 31,6 miesiąca, w przypadku stabilizacji choroby (SD, stable disease $)$-20,6 miesiąca, zaś u pacjentów $z$ chorobą w progresji - 10,2 miesiąca. Nie wykazano różnic w OS u chorych leczonych BV z wczesną i późną wznową po auto-HSCT. Najczęstszymi działaniami niepożądanymi leczenia były neuropatia czuciowa, nudności, zmęczenie, neutropenia i biegunka [20]. Po 3-letniej obserwacji spośród 102 chorych przy życiu pozostało 51 osób (50\%). Mediana OS w całej grupie wynosiła 40,5\%, a odsetek 3-letnich przeżyć - 54\%. Spośród 51 chorych ocenianych po 3 latach obserwacji w CR bez leczenia pozostawało 14 osób (u $5 \mathrm{z}$ nich wykonano konsolidację za pomocą allo-HSCT po leczeniu BV). Obecne wyniki tego badania wskazują, że mimo postępu, jakim jest wprowadzenie BV, rokowanie u chorych na HL w nawrocie po auto-HSCT pozostaje złe. Tym niemniej istnieje niewielka grupa pacjentów, która może uzyskać długoletnie przeżycie lub nawet zostać wyleczona za pomocą monoterapii przeciwciałem anty-CD30 [21].

Znane $z$ terapii chorych na nowotwory narządów litych przeciwciała anty-PD1 (progammed-cell death 1), których mechanizm działania polega na głównie na przywróceniu funkcji cytotoksycznych limfocytów T, okazały się zaskakująco skuteczne w HL. Po podaniu niwolumabu w badaniu 1. fazy ORR wyniósł $87 \%$, w tym $17 \% \mathrm{CR}(\mathrm{n}=4), 70 \% \mathrm{PR}$ $(\mathrm{n}=16)$, a SD uzyskano u kolejnych 3 osób $(13 \%)$. U 5 chorych wykonano następnie allo-HSCT, a u 1 - auto-HSCT. Po medianie obserwacji wynoszącej 24 tygodnie PFS wynosił 86\% [22]. Podobne badanie 1 . fazy dotyczyło innego przeciwciała anty-PD-1 - pembrolizumabu. Przedstawiono wstępne dane badania KEYNOTE-013 dotyczące leczenia 15 młodych chorych na HL (mediana wieku 28 lat) $z$ nawrotowa/oporną postacią HL. Mediana poprzednich linii leczenia wynosiła 4, wszyscy chorzy byli uprzednio leczeni BV, a $67 \%$ poddano wcześniej auto-HSCT. Leczenie było dobrze tolerowane; nie obserwowano poważnych działań niepożądanych. Zła tolerancja terapii była powodem jej przerwania tylko u 1 chorego. Również $\mathrm{w}$ tym badaniu obserwowano wysoką efektywność przeciwciała anty-PD1. Ogólny odsetek odpowiedzi wynosił 53\%, w tym u 3 chorych uzyskano CR (20\%), a u kolejnych 5 - PR (33\%) [23]. Skuteczność przeciwciał anty-PD1 w terapii chorych na nawrotową/oporną postać HL otwiera nowe możliwości leczenia tej niewielkiej, ale niekorzystnej rokowniczo grupy chorych.

\section{Monitorowanie chorych na HL po zakończeniu leczenia}

Optymalny sposób monitorowania chorych na HL po uzyskaniu pierwszej CR (CR1) pozostaje przedmiotem kontrowersji. Wielu klinicystów stosuje rutynowo powtarzane badania obrazowe, w tym PET/CT. Należy jednak podkreślić, że $\mathrm{PET} / \mathrm{CT}$ nie jest rekomendowane w tym wskazaniu [1]. Badacze $z$ Izraela i Nowej Zelandii porównali historyczną grupę pacjentów $(\mathrm{n}=305) \mathrm{w}$ CR1, u których rutynowo wykonywano badania obrazowe co 6 miesięcy przez 2 lata oraz dodatkowe badania w przypadku klinicznego podejrzenia wznowy choroby $z$ grupą chorych $\mathrm{w}$ CR1 bez zmian resztkowych $(n=63)$, których monitorowano jedynie za pomocą oceny klinicznej (wywiadu i badania lekarskiego). W drugiej grupie pacjentów badania obrazowe wykonywano tylko w przypadku podejrzenia wznowy HL. Pięcioletni OS wynosił $94 \%$, a mediana czasu do nawrotu $-8,6$ miesiąca, natomiast odsetek nawrotów wynosil, odpowiednio, w grupie historycznej $9 \%$, a w grupie badanej 13\%; 5-letni PFS nie różnił się między badanymi grupami. W grupie historycznej wykonano łącznie 1188 skanów (3,9/chorego), w tym 1084 w czasie rutynowej obserwacji, a $104 \mathrm{z}$ powodu podejrzenia wznowy choroby. Nawrót HL na podstawie rutyno- 
wych badań obrazowych wykryto jedynie u 17 pacjentów, u 8 chorych zaś — na podstawie objawów klinicznych. W grupie badanej wykonano tylko 38 skanów. W grupie historycznej zatem wykrycie jednej wznowy wymagało wykonania 47,5 skanu, natomiast $\mathrm{w}$ grupie badanej wystarczyło do tego 4,7 skanu. Autorzy konkludują, że u chorych w CR1 bez zmian resztkowych powtarzanie rutynowych badań obrazowych nie przynosi korzyści klinicznych, a jest bardzo kosztowne. W tej grupie pacjentów wystarczy monitorowanie poprzez systematyczne badanie lekarskie [24].

Innym negatywnym aspektem nadmiaru badań obrazowych jest wzmożona ekspozycja na promieniowanie jonizujące. Uważa się, że dawka kumulacyjna przekraczająca $75 \mathrm{mSv}$ wiąże się ze zwiększeniem o 7,3\% ryzyka wystąpienia wtórnych nowotworów. Retrospektywna analiza niemal 500 chorych na chłoniaki wykazała, że mediana dawki promieniowania związanego $z$ badaniami diagnostycznymi wynosi $69 \mathrm{mSv}$, ale jest ona wyższa u chorych poniżej 40. roku życia $(89 \mathrm{mSv}) . \mathrm{Na}$ dane te warto zwrócić uwagę szczególnie w kontekście młodych chorych $\mathrm{z}$ potencjalnie wyleczalną chorobą, jaką jest HL [25].

\section{Podsumowanie}

Współczesne wyniki leczenia u chorych na HL są doskonałym przykładem skuteczności chemioi radioterapii oraz leczenia skojarzonego. Jednak wydaje się, że klasyczne, opracowane w ubiegłym wieku, strategie postępowania przeciwnowotworowego osiągnęły już górny pułap swojej skuteczności, a niektóre stały się nieakceptowalne $z$ powodu toksyczności. Niewątpliwie największym osiągnięciem ostatnich lat było wprowadzenie do terapii chorych na HL przeciwciał monoklonalnych, w tym BV, pembrolizumabu i niwolumabu. Skuteczne wykorzystanie immunoterapii u chorych na HL z pewnością wykroczy wkrótce poza obecne wskazania do postaci nawrotowych i opornych.

\section{Piśmiennictwo}

1. Cheson B.D., Fisher R.I., Barrington S.F. i wsp. Recommendations for Initial Evaluation, Staging, and Response Assessment of Hodgkin and Non-Hodgkin Lymphoma: the Lugano Classification. J. Clin. Oncol. 2014; 32: 3059-3067.

2. Steidl C., Lee T., Shah S.P. i wsp. Tumor-associated macrophages and survival in classic Hodgkin's lymphoma. N. Engl. J. Med. 2010; 362: 875-885.

3. Deau B., Bachy E., Ribrag V. i wsp. macrophages and mast cells infiltration are biomarkers of primary refractory Hodgkin's lymphoma. Blood 2012; 120: 3881.
4. Connors J.M., Gascoyne R.D., Hopkins P. i wsp. Hodgkin lymphoma patients with stage II B or stage II bulky disease have advanced disease and should not be included in limited stage trials. Blood 2012; 120: abstrakt 417.

5. Diefenbach C., Li H., Hong F. i wsp. Evaluation of a novel 3 factor prognostic score (PS-3) for patients with advanced Hodgkin lymphoma (HL) treated on US Intergroup E2496. Blood 2013; 122: 4277.

6. Meyer R.M., Gospodarowicz M., Connors J.M. i wsp. ABVD alone versus radiation-based therapy in limited-stage Hodgkin's lymphoma. N. Engl. J. Med. 2012; 366: 399-408.

7. Radford J., Barrington S., Counsell N. i wsp. Involved field radiotherapy versus no further treatment in patients with clinical stages IA and IIA Hodgkin lymphoma and a 'negative' PET scan after 3 cycles ABVD. Results of the UK NCRI RAPID Trial. Blood 2012; 120: abstrakt 547.

8. Raemaekers J.M., André M.P., Federico M. i wsp. Omitting Radiotherapy in Early Positron Emission Tomography-Negative Stage I/II Hodgkin Lymphoma Is Associated With an Increased Risk of Early Relapse: Clinical Results of the Preplanned Interim Analysis of the Randomized EORTC/LYSA/FIL H10 Trial. J. Clin. Oncol. 2014; 32: 1188-1194.

9. Engert A., Kobe C., Markova J. i wsp. Assessment of residual bulky tumor using FDG-PET in patients with advanced-stage hodgkin lymphoma after completion of chemotherapy: final report of the GHSG HD15 Trial. Blood 2012; 120: abstrakt 764.

10. Skoetz N., Trelle S., Rancea M. i wsp. Effect of initial treatment strategy on survival of patients with advanced-stage Hodgkin's lymphoma: a systematic review and network meta-analysis. Lancet Oncol. 2013; 14: 943-952.

11. Merli F., Luminari S., Mammi C. i wsp. Long-term follow-up analysis of $\mathrm{HD} 2000$ trial comparing ABVD versus BEACOPP versus COPP/EBV/CAD in patients with newly diagnosed advancedstage Hodgkin's lymphoma: a study from the Fondazione Italiana Linfomi. Blood 2014; 124: abstrakt 499.

12. Ansell S.M., Connors J.M., Park S.I. i wsp. Frontline therapy with brentuximab vedotin combined with ABVD or AVD in patients with newly diagnosed advanced stage Hodgkin lymphoma. Blood 2013; 122: abstrakt 798.

13. Costa L.J., Excessive early mortality drives poor long term outcomes among older patients with classical Hodgkin lymphoma: a population study. Blood 2013; 122: abstrakt 1742.

14. Böll H., Görgen M., Fuchs M. i wsp. ABVD in older patients with early-stage Hodgkin lymphoma treated within the German Hodgkin Study Group HD10 and HD11 trials. J. Clin. Oncol. 2013; 31: 1522-1529.

15. Böll B., Brendenfeld H., Gorgen H. i wsp. Phase II study of PVAG (prednisolone, vinblastine, adriamycin, gemcitabine) in elderly patients with early unfavourable or advanced stage Hodgkin Lymphoma. Blood 2011; 118: 6292-6298.

16. Yasenchak A., Chen R., Sharmann J.P. Brentuximab vedotin frontline therapy for HL: interim phase II results. Blood 2013; 122: abstrakt 4389.

17. Anastasia A., Carlo-Stella C., Corradini P. i wsp. Bendamustine for Hodgkin lymphoma patients failing autologous or autologous and allogeneic stem cell transplantation: a retrospective study of the Fondazione Italiana Linfomi. Br. J. Haematol. 2014; 166: 140-142.

18. 18. Genzler R.D., Evens A.M., Rademaker A.W. i wsp. F-18 FDG-PET predicts outcomes for patients receiving total lymphoid irradiation and autologous blood stem-cell transplantation for relapsed and refractory Hodgkin lymphoma. Br. J. Haematol. 2014; 156: 793-800. 
19. Sureda A., Canals C., Arranz R. i wsp. Allogeneic stem cell transplantation after reduced intensity conditioning in patients with relapsed or refractory Hodgkin's lymphoma. Results of the HDR-ALLO study - a prospective clinical trial by the Grupo Español de Linfomas/Trasplante de Médula Osea (GEL/TAMO) and the Lymphoma Working Party of the European Group for Blood and Marrow Transplantation. Haematologica 2012; 97: 310-317.

20. Younes A., Gopal A.K., Smith S.E. i wsp. Results of a pivotal phase II study of brentuximab vedotin for patients with relapsed or refractory Hodgkin's lymphoma. J. Clin. Oncol. 2012; 30: 2183-2189.

21. Gopal A.K., Chen R., Smith S.E. i wsp. Three-year follow-up data and characterization of long-term remissions from an ongoing phase 2 study of brentuximab vedotin in patients with relapsed or refractory Hodgkin lymphoma. Blood 2013; 122: abstrakt 4382.
22. Ansell S.M., Lesokhin A.M., Borrello I. i wsp. PD-1 Blockade with nivolumab in relapsed or refractory Hodgkin's lymphoma. N. Engl. J. Med. 2015; 372: 311-319.

23. Moskowitz C.H., Ribrag V., Michot J.M. i wsp. PD-1 blockade with the monoclonal antibody pembrolizumab (MK-3475) in patients with classical Hodgkin lymphoma after brentuximab vedotin failure: preliminary results from a phase $1 \mathrm{~b}$ study (KEYNOTE-013). Blood 2014; 124: abstrakt 290.

24. Dann E.J., Berkahn L., Mashiah T. i wsp. Hodgkin lymphoma patients in first remission: routine positron emission tomography/computerized tomography imaging is not superior to clinical follow-up for patients with no residual mass. Br. J. Haematol. 2014; 164: 694-700.

25. Crowley M., O’Neill S.B., O’Neill D.C. i wsp. Radiation exposure from diagnostic imaging in patients with lymphoma - the cost of the cure? Blood 2013; 122: abstrakt 557. 